\title{
Penggunaan Media Story Book untuk Meningkatkan Pemahaman Siswa Pada Materi Hijrah Nabi Muhammad SAW ke Yatsrib Kelas IV Madrasah Ibtidaiyah Al-Hidayah Kasembon Bulu lawang Kabupaten Malang
}

\author{
Megawati Mahalil Asna \\ megawatimahalil@gmail.com \\ Sekolah Tinggi Agama Islam Sabilul Muttaqin Mojokerto
}

\begin{abstract}
Abstrak
Penelitian ini merupakan upaya untuk meningkatkan pemahaman Siswa Kelas IV MI Al-Hidayah Kasembon Bulu lawang Kabupaten Malang padamateri Hijrah Nabi Muhammad saw ke Yatsrib Mata Pelajaran Sejarah Kebudayaan Islam semester 2. Pertanyaan utama yang ingin di jawab pada penelitian ini adalah: (1) Bagaimanakah proses penggunaan Media Story Boo kpadapembelajaran SKI MateriHijrahNabi Muhammad saw ke Yatsrib pada Siswa kelas IV Madrasah Ibtidaiyah Al-Hidayah Kasembon Bulu lawang ? (2) bagaimana peningkatan pemahaman Sejarah Kebudayaan Islam (SKI) melalui media Story Book pada SiswaKelas IV Madrasah Ibtidaiyah Al-Hidayah Kasembon Bulu lawang Kabupaten Malang? Untuk menjawab pertanyaan tersebut maka penelitian ini menggunakan pendekatan dengan penelitian tindakan kelas.

Penelitian tindakan kelas ini dilaksanakan tanggal 03 September 2020 sampai 10 Oktober 2020 dan terdiri dari 2 siklus dan satu siklus terdiri atas dua jam pelajaran atau satu kali pertemuan. Temuan penelitian ini menunjukkan bahwa dalam penyampaian materi sebelumnya guru menyampaikan materi HijrahNabi Muhammad saw ke Yatsrib matapelajaran Sejarah Kebudayaan Islam sebelumnya menggunakan metode ceramah yakni guru menyampaikan dengan ceramah dan siswa hanya mendengarkan dengan hanya sesekali di beri kesempatan untuk bertanya.

Pemahaman siswa tentang materi Isra' Mi'raj yang di ajarkan dengan metode ceramah sangat rendah. Dari hasil tesulangan harian siswa, dari jumlah 32 siswa hanya sekitar 8 siswa (31\%) yang mampu memahami materi Isra' Mi'raj dan memperoleh hasil yang maksimal atau mencapai batas ketuntasan belajar minimal mereka. Sedangkan sisanya (65\%) sekitar 28 siswa memperoleh rata-rata nilai di bawah 60 .
\end{abstract}

Kata Kunci: Media Story Book; PeningkatanPemahaman 


\section{PENDAHULUAN}

Berdasarkan hasilwawancara dengan guru Sejarah Kebudayaan Islam (SKI) Kelas IV Madrasah Ibtidaiyah Al-Hidayah Kasembon Bululawang. Yang menjadi masalah dikelas ini adalah siswa yang merasa bosan disaat pembelajaran. Dimana disaat pembelajaran guru hanya menggunakan metode ceramah dan Tanya jawab. Sehingga siswa mengalami kesulitan dalam memahami pelajaran. Hal ini menjadikan siswa kelas IV Madrasah Ibtidaiyah (MI) Al-Hidayah Kasembon Bululawang kurang memperhatikan guru saat pembelajaran. Sedangkan disekolah tersebut diketahui bahwa strategi dan teknik pembelajaran kurang optimal yang digunakan pada pembelajaran Sejarah Kebudayaan Islam siswa kelas IV Madrasah Ibtidaiyah Al-hidayah Kasembon Bululawang tergolong masih rendah padahal kemampuan siswa terhadap materi cukup baik. Disaat pembelajaran guru yang hanya menggunakan metode ceramah nilai siswa rata-rata dibawah KKM. Dimana nilai siswa tersebut hanya 35-50 dan belum mencapai KKM.

Demikian juga pada guru madrasah bahkan hampir tidak dibekali dengan metodologi pembelajaran inovatif dan belajar aktif. Hal ini juga didukung dengan minimnya bahkan tidak tepatnya fasilitas pembelajaran sebagai peningkatan pembelajaran. Di madrasah namun pada kenyataannya, pendidikan bukanlahsuatu upaya yang sederhana melainkan suatu kegiatan yang dinamis dan penuh tantangan yang akan selalu berubah seiring dengan perubahan zaman. Guru tidak cukup hanya mampu menyampaikan materi pembelajaran, tetapi harus mampu mentransformasi atau membelajarkan materi dengan tujuan siswa dapat menerima materi tersebut dengan baik.

Dengan demikian pemahaman guru terhadap pribadi siswa diharapkan mampu membimbing dan mengarahkan siswa agar dapat memahami akan materi pelajaran yang diberikan dengan baik. Baik menggunakan metode pengajaran tertentu maupun pendekatan guru terhadap siswa sendiri. 
Berdasarkan permasalahan diatas supaya siswa tidak merasa bosan dalam pembelajaran Sejarah Kebudayaan Islam (SKI). Maka dari itu guru akan menggunakan media Story Book dalam pembelajaran Sejarah Kebudayaan Islam (SKI). Untuk meningkatkan pemahaman siswa dalam materi Sejarah Kebudayaan Islam (SKI). Maka dari itu saya merasa tertarik untuk membahas lebih dengan mengadakan penelitian dengan judul Penggunaan Media Story Book untuk Meningkatkan Pemahaman Siswa pada Mata Pelajaran Sejarah Kebudayaan Islam Materi Hijrah Nabi Muhammad saw. Ke Yatsrib Kelas IV MIAl-Hidayah Kasembon Bululawang Kabupaten Malang.

Dengan menggunakan Media Story Book agar supaya siswa tidak merasa bosan atau jenuh disaat pembelajaran sehingga siswa lebih memahami pembelajaran dengan menggunakan media tersebut.

Adapun tujuan penelitian ini adalah dalam penggunaan media Story Book kegiatan pembelajaran terlaksana dengan baik dan lancar. Adapun perencanaan pembelajaran dengan menggunakan media Story Book adalah denganlangkah-langkah penggunaan media Story Book

(1) Wajib membaca sumber asli yakni buku pelajaran yang telah dipelajari, kemudian dilanjutkan dengan menggunakan media Story Book.(2) Siswa membaca Story Book bagian depan terlebih dahulu, kemudian siswa harus dapat menjawab apa yang di tanyakan sesuai dengan gambar yang ada dibagian belakangnya.

Dalam kegiatan pelaksanaan dan observasi pembelajaran pada siklus I pertemuan pertama, siswa tanpak senang menyambut guru pengajar dengan member senyum dan guru membalas senyum sebagai tanda member respon sebagian siswa ada yang menghampiri guru untuk bersalaman mencium tangan guru, guru membagi materi dalam bentuk gambar-gambar Hijrah Nabi Muhammad saw ke Yatsrib siswa terlihat lebih tertarik dan lebih semangat belajarnya guru meminta siswa untuk memahami gambar tersebut Ada satu siswa laki-laki yang tidak mendengarkan yang terlihat bermain sendiri dan masih malu untuk bertanya di dapan kelas 
Sedangkan pada siklus II terjadi perubahan pertemuan pertama, seperti biasa siswa tanpak senang menyambut guru pengajar dengan member senyum dan guru membalas senyum sebagai tanda member respon. Guru membagikan buku cerita dengan bentuk foto copy siswa tampak lebih tertarik dan lebih semangat belajarnya guru meminta siswa untuk lebih memahami tentang isi buku tersebut dan guru juga meminta siswa untuk bertanya apa yang tidak dimengerti, siswa sudah tidak malu lagi untuk bertanya di depan kelas.

Penelitian ini menunjukkan adanya peningkatan pemahaman siswa yang terlihat dari tes tiap siklusnya mulai dari siklus I sampai siklus II,pada siklus I rata-rata nilai siswa adalah 67,68 dengan persentase ketuntasan sebesar 99,8\% kemudian pada siklus II meningkat nilai rata-rata siswa menjadi 77,50 dengan persentase ketuntasannya 93,7\%. Dari data tersebut diambil kesimpulan bahwa terjadi peningkatan presentase siswa yang paham dengan materi yang disampaikan. Hal tersebut dikarenakan standar Kriteria Ketuntasan Minimal siswa dikatakan tuntas sebesar 75

\section{METODE PENELITIAN}

Sesuai dengan jenis penelitian yang di pilih,yaitu penelitian tindakan kelas maka penelitian ini menggunakan model penelitian tindakan dari Kemmis dan Taggart yaitu berbentuk spiral dari siklus yang satu ke siklus berikutnya (Arikunto, 2013:137). Setiap siklus meliputi planning (rencana), action (tindakan), observation (pengamatan ), dan reflection (refleksi ).

Adapun model PTK dimaksud menggambarkan adanya empat langkah (dan pengulangannya), yang disajikan dalam bagan ini.

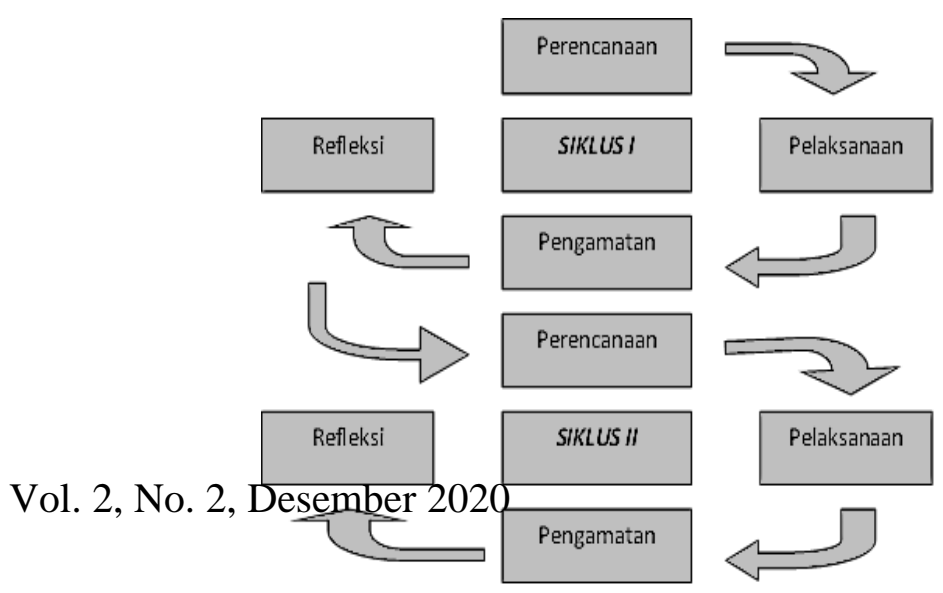


Subjek yang diteliti dalam penelitian ini adalah siswa kelas IV MI AlHidayah Kasembon Bulu lawang dengan jumlah 32 siswa. Instrumen yang digunakan dalam penelitian ini adalah sebagai berikut: a) Rencana Pelaksanaan pembelajaran yang digunakan sebagai pedoman guru b) Lembar kegiatan siswa ini yang dipergunakan siswa untuk membantu proses pengumpulan dan hasil kegiatan pemberiantugas. c) Lembar tes bertujuan sebagai alat ukur dalam proses evaluasi d) instrument wawancara (Arikunto, 2002:149). Teknik yang digunakan untuk mengumpulkan data dalam penelitian ini adalah: 1) Metode observasi merupakan sebagai pencatatan sistematik fenomena-fenomena yang diselidiki 2) wawancarapercakapan yang dilakukan oleh dua pihak 3) Tes merupakan pengumpulan data untuk mengukur kemampuan siswa dalam aspek kognitif, atau tingkatan penguasaan materi pelajaran (Sanjaya, 2015:99).

Analisis data dilakukan setiap siklus pembelajaran berahir.Data mengenaihasil belajar yang diperoleh sebagai berikut. 1) aktivitas belajar. 2) hasil belajar. Skor yang didapat siswa kemudian dibandingkan dengan Kriteria Ketuntasan Minimal sekolah yaitu 75.Jadi seorang siswa dikatakan tuntas belajar jika mencapai skor> 75.Bentuk tabel yang digunakan untuk mentabulasi data berdasarkan tes akhir siklus. Penelitian ini terdiri dari dua siklus. Pelaksanaan penelitian ini terdiri dari 4 tahap yaitu perencanaan tindakan, pelaksanaan tindakan, observasi/ pengamatan, refleksi.

\section{HASIL PENELITIAN DAN PEMBAHASAN}

Guru perlu menguasai bahan pembelajaran yang akan disampaikan kepada siswa dengan baik, memiliki keterampilan untuk menggunakan media sangat diperlukan. Kalau perlu untuk memperlancarkan menyampaikan materi kepada siswa dengan menggunakan media Story Book maka perlu melakukan latihan berulang-ulang tanpa harus dihadapan siswa secara langsung. Mempersiapkan Story Book 
Sebelum dimulai pembelajaran pastikan bahwa Media Story Bookapakah sudah bisa digunakan, mengecek kembali apakah sudah benar-benar siap dan perlu tidaknya media lain untuk membantu.Mempersiapkan tempat

Hal tersebut berkaitan dengan posisi guru sebagai penyampai materi pembelajaran apakah sudah tepat berada pada posisi tengah-tengah siswa, penataan ruangan yang baik dan rapi, serta pencahayaan yang cukup sehingga seluruh siswa lebih semangat dalam menerima pelajaran.

Darikegiatan pembelajaran yang telah berlangsung dengan menggunakan media Story Book dalam kegiatan awal penerapan metode ini, guru masuk kelas dengan mengucapkan salam, berdo'a bersama, melakukan presensi, menanyakan kabar siswa, memberikan motivasi, menyampaikan tujuan pembelajaran, mengaitkan pembelajaran dengan pelajaran yang telah dipelajari, kemudian dilanjutkan dengan kegiatan inti yaitu guru membagikan sebuah gambar yang menarik tentang gambar Hijrah Nabi Muhammad saw ke Yatsrib, kemudian guru menjelaskan materi tentang Hijrah, sebab-sebab dan peritiwa Hijrah Nabi Muhammad saw ke Yatsrib pada siklus I dengan memberikan pertanyaan ke siswa sebutkan sebab-sebab Nabi Hijrah ke Madinah.

Pada siklus II peningkatan pemahaman siswa tentang materi Hijrah Nabi Muhammad saw ke Yatsrib sudah baik dan hasil belajar siswa lebih meningkat dibandingkan dengan siklus I, akan tetapi pada siklus II hanya satu siswa yang belum mencapai ketuntasan kriteria minimum (KKM) dikarenakan siswa tersebut izin tidak masuk sekolah perlu dampingan khusus pada saat proses pembelajaran. Guru dalam penggunaan media Story Booksudah lebih baik dari siklus I, terbukti guru sudah lebih rileks dalam penggunaan media tersebut tanpa ada rasa terburu-buru dalam menjelaskan kepada siswa. 


\section{SIMPULAN}

Sebagai seorang pengajar harus mengetahui bahwasanya kemampuan belajar peserta didik sangat menentukan keberhasilannya. Di dalam proses belajar tersebut, banyak faktor yang mempengaruhinya, antara lain:

1) Motivasi Motivasi adalah kondisi fisiologis dan psikologis yang terdapat dalam diri seseorang yang mendorongnya untuk melakukan aktivitas tertentu guna mencapai suatu tujuan (kebutuhan)

2) Sikap belajarSikap belajar siswa akan berwujud dalam bentuk perasaan senang atau tidak senang, setuju atau tidak setuju, suka atau tidak suka terhadap hal-hal tersebut. Sikap seperti itu akan berpengaruh terhadap proses dan hasil belajar yang dicapainya

3) Minat adalah rasa lebih suka dan rasa ketertarikan pada suatu hal atau aktivitas, tanpa ada yang menyuruh

4) Kebiasaan belajarKebiasaan belajar dapat diartikan sebagai cara atau teknik yang menetap pada diri siswa pada waktu menerima pelajaran, membaca buku, mengerjakan tugas, dan pengaturan waktu untuk menyelesaikan kegiatan.

5) Konsep diriKonsep diri adalah pandangan seseorang tentang dirinya sendiri yang menyangkut apa yang ia ketahui dan rasakan tentang perilakunya, isi pikiran dan perasaannya, serta bagaimana perilakunya tersebut berpengaruh terhadap orang lain.

Vol. 2, No. 2, Desember 2020 
BADA'A: Jurnal Ilmiah Pendidikan Dasar

Vol. 2, No. 2, Desember 2020, Hal. 211-218

E-ISSN: 2714-7711

\section{DAFTAR PUSTAKA}

Arief S. Sadjiman, M.Sc (dkk) 2012 media pendidikan pengertian, pengembangan, dan pemanfaatan.PT. Raja Grafindo Persada jakarta dalam rangka ECD Project (USAID)

Azhar Arsyad, M.A. 2014-2015 Media Pembelajaran PT. Rajagrafindo persada, jakarta.

Arikunto, Suharsimi. 2006. Prosedur Penelitian Suatu Pendekatan Praktik. Jakarta: PT Rineka Cipta.

Anita, Sri. 2010. Media Pembelajaran. Surakarta : Yuma Pressindo.

Arikunto, Suharsimi 2013. Prosedur Penelitian Suatu PendekatanPraktik, Jakarta: PT Rineka Cipta.

Asnawir 2002 Media Pembelajaran. Jakarta :PT. Intermasa.

Daryanto 2010-2013 media pembelajaran PT. GAVA MEDIA yogyakarta

Daryanto. 1993. Media Visual Untuk Pengajaran Teknik. Bandung

J. Moleong, Lexy. 2011. Metodologi Penelitian Kualitatif. Bandung: PT Remaja Rosakarya.

Muslich Mansur. 2009. Melaksanakan Penelitian Tindakan Kelas itu Mudah. Jakarta: PT Bumi Aksara

MochNazir. 2003, Metode Penelitian. Jakarta :Ghalia Indonesia.

Max Darsono dkk, 2000 Belajar dan Pembelajaran, Semarang :IKIP Semarang Press,

Nana Sudjana (dkk) 2009-2010 Media Pengajaran PT. Sinar Baru Algensindo Bandung.

Nasution, S. 2014. Metode Reseach. Jakarta: BumiAksara

Sugiyono. (2005) .Metode Penelitian Pendidikan ,Pendekatan kuantitatif, kualitatif, dan $R \& D$ Bandung : ALFABETA.

Vol. 2, No. 2, Desember 2020 